Izvorni članak UDK 115(045)

doi: $10.21464 /$ fi38310

Primljeno: 14. 8. 2018.

\title{
Igor Martinjak
}

Sveučilište u Zagrebu, Fakultet filozofije i religijskih znanosti, Jordanovac 110, HR-10000 Zagreb igor.martinjak@yahoo.com

\section{Aristotelova psihologijska koncepcija značenja: $\pi \alpha \theta \eta ́ p \alpha \tau \alpha$ kao ó $\mu \circ \iota^{\prime} \mu \alpha \tau \alpha$}

\begin{abstract}
Sažetak
U ovom tekstu razmatram Aristotelovu psihologijsku koncepciju značenja. Pokazat ću da u spisu $\mathrm{O}$ tumačenju možemo pronaći takvu koncepciju značenja koja omogućuje odgovor na tipične prigovore psihologijskim koncepcijama značenja. Sukladno mojoj interpretaciji zahtijeva se da su misli, a ne mentalne slike, significata naših termina. Naime, mentalne slike mogu biti subjektivna svojstva pojedinog uma u pojedinom vremenskom periodu, međutim, misli kao izomorfne nalike univerzalnog $i$ nužnog aspekta izvanmentalne zbilje pružaju osnovu za intersubjektivnost koja se zahtijeva u adekvatnom objašnjenju značenja. U takvoj interpretaciji referencija nije fiksirana kroz relaciju nalikovanja jer se mentalni sadržaj nereferirajućeg termina također osigurava kroz relaciju nalikovanja između neke misli i dva ili više izvanmentalnih entiteta.
\end{abstract}

\section{Ključne riječi}

dojmovi u duši, misli, mentalne slike, nalike, izvanmentalna zbilja, značenje, referencija

Univerzum je pun magičnih stvari koje strpljivo čekaju da naš um postane britkiji

Eden Phillpotts, A Shadow Passes, 1918.

I.

Iako interpreti nisu suglasni oko svih detalja Aristotelova razmatranja jezika, svi se na neki način slažu da mentalni entiteti igraju ključnu ulogu u objašnjenju značenjskih činjenica - homonimija, sinonimija, razumijevanje novih i ne-izrečenih rečenica itd. Naime, jezičnu homonimiju i sinonimiju objašnjavamo kao označavanje različitih, odnosno istih mentalnih entiteta, a razumijevanje novih i složenih rečenica objašnjavamo na osnovi poznavanja sintaktičkih pravila te značenja jednostavnih izričaja. Međutim, ako Aristotelova koncepcija značenja ima takav psihologijski karakter, onda se suočava s brojnim uvjerljivim prigovorima. Naime, ako je značenje pojam, kako onda možemo necirkularno definirati pojam neovisno od značenja, ako nije jasno što bi bio pojam ako ne naša koncepcija nečega. Ali značenje riječi ' $\mathrm{X}$ ' prema psihologizmu jest upravo neka naša koncepcija X-a. Ako su pak mentalne slike significata, onda je teorija posve neadekvatna jer zasigurno ne možemo slikovno predočiti tisućukutnik. Ipak, najveći problem mentalističkim teorijama predstavlja problem intersubjektivnosti. Kako je moguće da značenje bude u glavi, a da svaki kompetentan govornik nekog jezika može s 
lakoćom razumjeti bilo koju smislenu rečenicu sugovornika? Značenje promatramo kao društveni fenomen te bismo htjeli da ono bude utemeljeno $u$ nečem univerzalnom i izvanmentalnom.

No Aristotel inzistira na tome da su $\pi \alpha \theta \eta \dot{\mu} \mu \alpha \tau \alpha$, kao ono što je označeno jezičnim entitetima, na neki način nalike, tj. ó $\mu$ otó $\mu \alpha \tau \alpha$ izvanjezične i izvanmentalne stvarnosti. Međutim, sam fenomen nalikovanja ima snažnu fotografijsku konotaciju, stoga se čini da naše riječi doista označavaju mentalne slike koje nalikuju elementima stvarnosti. Ali kako Aristotel u tom slučaju može tvrditi da termini 'jaracjelen' i 'kentaur' nešto znače, ako ne možemo u stvarnosti pronaći ništa jedinstveno čemu bi takve mentalne slike odgovarale? Da bismo objasnili sve značenjske činjenice i probleme koji proizlaze iz mentalističkog aspekta značenja, potrebno je odgovoriti na dva pitanja: što su relata relacije nalikovanja te koja je narav te relacije, odnosno pretpostavlja li se doista da su significata mentalne slike koje fotografijski nalikuju vanjskim predmetima. Jasno je da su pitanja povezana jer ako significata nisu mentalne slike, ne možemo govoriti o fotografijskom nalikovanju i obratno.

Moja je namjera u ovom tekstu identificirati upravo relata relacije nalikovanja te odrediti samu narav te relacije, kao i objasniti kakvu točno ulogu u označavanju imaju (slikovne) predodžbe. Tvrdit ću da su significata misli, odnosno koncepcije u kojima je sadržan formalni i nužni aspekt stvarnosti, te da je naš umski dio duše, analogno osjetilnom dijelu duše, po svojoj naravi sposoban primati inteligibilne forme, tj. nužni i univerzalni aspekt konkretnih predmeta. Nalikovanje u tom slučaju nema nikakvu fotografijsku konotaciju jer se jednostavno radi o tipskom identitetu, odnosno izomorfizmu jednostavnih misli i formalnog aspekta nekog izvanmentalnog predmeta. Međutim, prema takvoj interpretaciji psihologizma, funkcija nalikovanja nije osigurati referenciju, nego objasniti pluralitet misli na osnovi izvanmentalne stvarnosti. Što se tiče mentalnih predodžbi, one se ne mogu poistovjetiti s mislima, ali ih uvijek prate jer dok izričemo riječ ‘čovjek' svi podrazumijevamo dvonožnu kopnenu životinju, no netko pred očima ima pojedinačnost u odijelu, netko demi-mondaine, a netko sportaša na terenu itd.

II.

\section{II. $I$.}

Pitanje naravi relacije nalikovanja, kao i njenih elemenata, u literaturi je dosta raznovrsno tretirano iz nekoliko razloga. Prije svega, nije jasno koja bi trebala biti tekstualna evidencija za objašnjenje spomenutih pitanja. Brojni odlomci iz Aristotelova korpusa za koje se čini da pružaju nekakvo objašnjenje često su različito interpretirani te su tumači skloni selektivno tretirati i tražiti evidenciju za potkrepu svojih postavki, u potpunosti ignorirajući neke druge odlomke iz korpusa, kojih nisu svjesni ili koji bi mogli predstavljati problem za njihove pozicije. Sukladno rečenome, neki tumači misle da Aristotel uopće nema teoriju značenja ili da je ona posve neadekvatna, dok drugi pak smatraju da bismo mogli pronaći jezgru teorije značenja, ali nisu suglasni oko karaktera te teorije. Također, neki misle da su relata isključivo mentalne slikovite predodžbe te izvanjezična i izvanmentalna stvarnost koja je fotografski pohranjena u umu te dostupna za označavanje, dok su drugi spremni significata tretirati ipak kao nešto što nema piktografski karakter.

Prema tome, potrebno je utvrditi koji nam tekstualni odlomci i kako mogu poslužiti kao evidencija za odgovor na naša temeljna pitanja. Prvi takav, koji je 
od Kretzmanna kvalificiran kao najutjecajniji odlomak u povijesti semantike (De int. 1, 16a3-9), vrijedi citirati u cijelosti, u izvorniku i prijevodu.

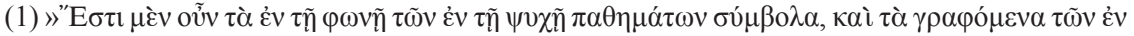

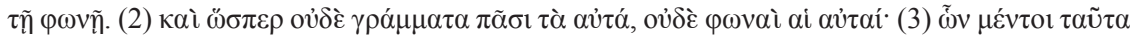

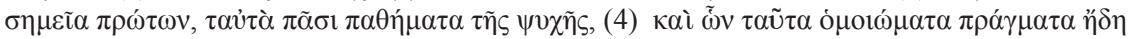

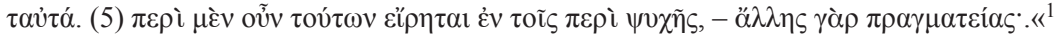

U ovom se odlomku nalazi ishodište naših dvaju pitanja - kakva je narav relacije nalikovanja te koja su relata te relacije - ali je naznačeno i mjesto gdje bismo na ta pitanja trebali pronaći odgovor. Tvrdnjom (1) Aristotel nam kazuje da postoje dva aspekta materijalne strane jezičnog znaka, njegov fonetski i grafijski aspekt. U tvrdnji (2) možemo uočiti da je Aristotel svjestan varijeteta fonetskog i grafijskog aspekta jezičnog znaka između naroda, država, plemena itd., dok u (3) saznajemo da se jezični znaci, neovisno o svojoj različitoj materijalnoj strani, mogu smatrati istovrijednima na osnovi iste sadržajne strane, naime, na osnovi onoga što označuju. Ovdje tek počinju nama relevantni problemi jer imamo eksplicitnu tvrdnju da je significatum $\pi \alpha ́ \theta \eta \mu \alpha$ kao mentalni entitet, stoga iskrsavaju sva pitanja povezana s psihologijskim teorijama značenja. Ipak, moguće se rješenje krije u nastavku jer Aristotel također u (3) tvrdi da su to za sve ljude ista $\pi \alpha \theta \eta \dot{\mu} \mu \alpha \tau \alpha$, što nam može sugerirati da se ne radi o privatnom jeziku. Objašnjenje pak zašto su $\pi \alpha \theta \eta \dot{\mu} \mu \alpha \tau \alpha$ ista za sve ljude krije se u (4) gdje se kaže da $\pi \alpha \theta \eta ́ \mu \alpha \tau \alpha$ nalikuju o umu i jeziku neovisnoj stvarnosti. U tvrdnji (5) Aristotel nas konačno upućuje na to da o tim pitanjima odgovor potražimo u drugom spisu koji se tiče drugog predmeta rasprave.

Iz ovoga je nedvojbeno jasno da naši jezični izričaji označavaju mentalne entitete, svojevrsne $\pi \alpha \theta \eta \dot{\mu} \mu \alpha \alpha$, kao i to da je Aristotel na neki način svjestan problema privatnog jezika ${ }^{2}$ kojemu pokušava doskočiti tvrdeći da su ti mentalni entiteti ó $\mu$ ot $\mu \alpha \tau \alpha$ izvanjezične i izvanmentalne zbilje $(\pi \rho \alpha ́ \gamma \mu \alpha \tau \alpha)$, što ih čini jednakima za sve ljude. Međutim, nije jasno što doista jesu $\pi \alpha \theta \eta \dot{\mu} \mu \alpha \tau \alpha$ i što točno znači da su ó $\mu$ oí́ $\mu \alpha \tau \alpha$. Također, nije posve jasno na što referira izraz $\dot{\varepsilon} v$ $\tau o i \varsigma \varsigma \pi \varepsilon \rho \grave{~} \psi v \chi \tilde{\eta} \varsigma$, tj. koji je to predmet rasprave i gdje koji nije u toj mjeri relevantan za predmet rasprave u spisu $O$ tumačenju. Što se tiče zadnjeg pitanja, vjerujem da Aristotel misli upravo na slučajeve iz spisa $O$ duši gdje se govori

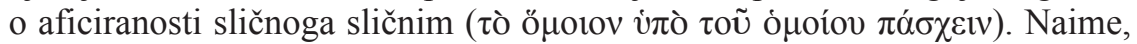
$\pi \alpha \theta \eta ́ n \alpha \tau \alpha$ su upravo afekcije od strane nečega sličnog, tj. nalik - stoga se $u$ (5) Aristotel direktno nadovezuje na to da $\pi \alpha \theta \eta \dot{\eta} \mu \alpha \tau \alpha$ nalikuju $\pi \rho \alpha ́ \gamma \gamma \mu \alpha \tau \alpha$, a ne toliko na tvrdnje (1)-(3) o materijalnoj i sadržajnoj strani jezičnog znaka. Činjenica da su $\pi \alpha \theta \eta \dot{\mu} \mu \alpha \alpha$ nalike $\pi \rho \alpha ́ \gamma \mu \alpha \tau \alpha$ nije toliko bitna za određivanje

»(1) Postoji dakle ono što je dano u izričaju i to su simboli dojmova u duši, a ono što je napisano simboli su onoga što je dano u izričaju. (2) I kao što nisu ni sva pisma ista za sve ljude, tako nisu ni izričaji isti; (3) no zacijelo prvotnih stvari $(\pi \rho \omega ́ \tau \omega v)$ čega su ti [=izričaji i pisma] znaci su za sve ljude isti dojmovi u duši, (4) a već su iste i stvari čega su ti [=dojmovi u duši] nalike. (5) O tome je dakle kazano u spisima o duši - a to se pak tiče druge rasprave.« Vidi: Norman Kretzmann, »Aristotle on Spoken Sound Significant on Convention«, u: John Corcoran (ur.), Ancient Logic and its Modern Interpretations, Reidel, Dordrecht, Boston 1974., str. 3-12, str. 3.
Aristotel dakako nije svjestan suvremenog problema privatnog jezika, nego nastoji pokazati kako je naša duša po svojoj prirodi sposobna izomorfno primati aspekte zbilje koji će biti objelodanjeni $u$ istinitim rečenicama. Naime, tvrdnja da naše izjavne rečenice imaju takvu strukturu kakvu imaju proizlazi iz njegova mišljenja da svijet ima sličnu strukturu, a subjektno-predikatna struktura naših rečenica jednostavno izražava takvu kompleksnost naših mentalnih entiteta $\mathrm{u}$ jedinstveno vjerovanje koje, ako je istinito, izomorfno korespondira sa strukturom svijeta. Naravno, rješenje za problem privatnog jezika proizlazi iz toga - kako će biti pokazano u ostatku teksta. 
kontradiktornih parova, kao ultimativnog cilja spisa $O$ tumačenju, ali ju je opet potrebno tek spomenuti jer istinitost rečenica u konačnici ovisi upravo o $\pi \rho \alpha ́ \gamma \mu \alpha \tau \alpha^{3}$

Štoviše, Aristotel u spisu $O$ tumačenju nije toliko zainteresiran za sama $\pi \alpha \theta \eta \dot{\mu} \mu \alpha \tau \alpha$ općenito jer već u sljedećem retku $\left(1,16^{\mathrm{a} 9-10)}\right.$ počinje govori-

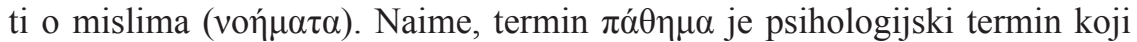
trebamo prevesti kao 'utisak', 'afekcija' ili 'dojam', što sugerira da je proizveden od nekoga vanjskog predmeta i pohranjen u našu dušu. ${ }^{4} \mathrm{U}$ spisu $O$ duši već u prvom poglavlju čitamo da su te $\pi \alpha \theta \eta \dot{\mu} \mu \alpha \tau \alpha$ različiti osjetilni podatci $(\alpha i \sigma \theta \eta \dot{\mu} \mu \tau \alpha)$, predodžbe ( $\varphi \alpha \nu \tau \alpha ́ \sigma \mu \alpha \tau \alpha)$, razne emocije i spomenute misli

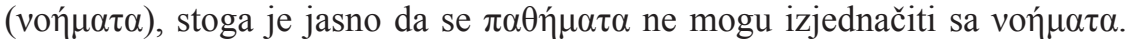
Prema tome, izgleda da su Aristotelu u spisu $O$ tumačenju relevantna samo ona $\pi \alpha \theta \eta \dot{\mu} \alpha \tau \alpha$ koja se mogu kombinirati u istinitosno afirmativno ili negativno vjerovanje, ${ }^{5} \mathrm{tj}$. u složenu misao nastalu kombinacijom jednostavnih misli. Objašnjenje pak kako jednostavne misli kao $\pi \alpha \theta \eta ́ \mu \alpha \tau \alpha$ nalikuju stvarnosti treba tražiti u onim poglavljima u spisu $O$ duši gdje se govori o tome kako je osjetilni i intelektualni dio duše aficiran od strane vanjskog predmeta.

\section{II.}

Čini se da smo identificirali relata relacije nalikovanja - naime, s jedne strane, imamo misli, a s druge, tipične pripadnike kategorijske razdiobe, kao o umu i jeziku neovisne elemente stvarnosti. U spisi $O$ tumačenju saznat ćemo pomoću kojih se sve sintaktičkih mogućnosti naši jednostavni izričaji mogu kombinirati u složene afirmativne ili negativne iskaze, koji u konačnici odgovaraju složenim mislima, tj. našim vjerovanjima, a u spisu $O$ duši saznat ćemo što je to točno nalikovanje i na osnovi čega naše jednostavne misli uspijevaju biti o elementima stvarnosti. Ipak, ne misle svi tako. Ackrill ${ }^{6}$ smatra da su significata jednostavnih izričaja mentalne (slikovite) predodžbe, tj.

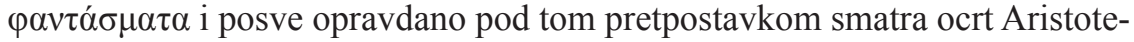
love teorije značenja neadekvatnim jer naša mentalna slika pegaza ne može nalikovati ničemu jedinstvenom u svijetu. Kretzmann ${ }^{7}$ je upravo zbog tog prigovora smatrao da najutjecajniji odlomak u povijesti semantike uopće ne predstavlja semantičku teoriju kroz psihologijsku i epistemološku prizmu koja bi dovodila u odnos jezik i svijet, nego da samo uspostavlja konvencionalizam $^{8}$ pri formiranju materijalne strane jezičnog znaka.

Sva ovakva mišljenja pretpostavljaju fotografijski aspekt nalikovanja, međutim, Aristotel terminom ó $\mu$ oí $\omega \mu \alpha$ želi reći puno više od same fotografijske sličnosti i De Rijk ${ }^{9}$ s razlogom tvrdi da je određenje ó $\mu$ ot $\mu \alpha \tau \alpha$ presudno za preciziranje Aristotelove semantičke teorije. De Rijk, ${ }^{10}$ Carson $^{11}$ te NoriegaOlmos $^{12}$ razmatraju različitu upotrebu izraza ó $\mu$ oí $\omega \mu \alpha$ kroz Aristotelov korpus. Tako navode Aristotelove primjere gdje se tvrdi da neki politički sustav u jednoj zemlji može biti ó $\mu$ oí $\mu \alpha$ političkog sustava neke druge zemlje, da

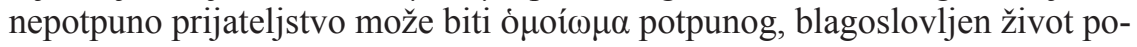
jedinca ó $\mu$ oí$\omega \mu \alpha$ života bogova, retorika kao ó $\mu$ oí $\omega \mu \alpha$ dijalektici i sl. Jasno je da ovakva upotreba ó $\mu$ otó $\mu \alpha \tau \alpha$ isključuje fotografijko nalikovanje. Iz ovih primjera spomenuti autori zaključuju: ó $\mu$ oí $\omega \mu \alpha$ je nešto što na adekvatan način reprezentira narav predmeta; ${ }^{13}$ ó $\mu$ oí $\omega \mu \alpha$ je kauzalno slična svojem predmetu, ali ne u cijelosti identična; ${ }^{14}$ izraz ó $\mu$ oí $\omega \mu \alpha$ upućuje na posjedovanje nečeg zajedničkog ${ }^{15} \mathrm{~s}$ odgovarajućim predmetom. ${ }^{16}$

Ovakva nefotografijska shvaćanja ó $\mu$ ot $\mu \alpha \tau \alpha$ odgovaraju Aristotelovu objašnjenju nastanka pojedinih $\pi \alpha \theta \eta \dot{\mu} \mu \alpha \tau \alpha$ u spisu $O d u \check{s} i$. Tako, primjerice, kada

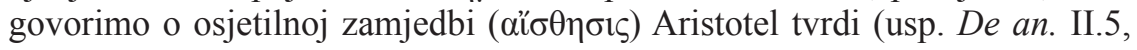




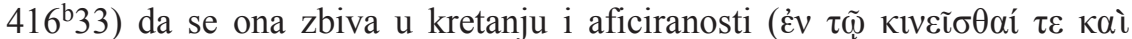
$\pi \alpha ́ \sigma \chi \varepsilon \imath$ ) gdje predmet izvana ( $\tau$ ò $̌ \xi \xi \omega)$ mora potaknuti aktualiziranje nečega

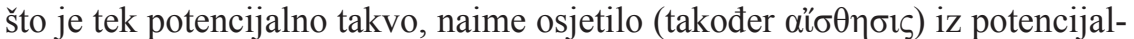
no sličnog postaje aktualno slično (őhotos) predmetu što ga zamjećuje i koji aktualno ima to svojstvo koje osjetilo aktualizira (usp. II.5, 417 a 4-21). To se dotično svojstvo kasnije (usp. De an. II.12, 424a 17-18) naziva »osjetilna

U Kategorijama (12, 14 $\left.{ }^{\mathrm{b}} 21-22\right)$ tako čitamo da je iskaz istinit zato što postoje tako strukturirane $\pi \rho \alpha ́ \gamma \mu \alpha \tau \alpha$, a ne da postoje tako strukturirane $\pi \rho \alpha ́ \gamma \mu \alpha \tau \alpha$ zato što je iskaz istinit. Ova se tvrdnja može smatrati okosnicom suvremene truth-making teorije prema kojoj su iskazi učinjeni istinitima time što je izvanjezična stvarnost takva i takva, a ne obratno. Prema tome, stvarnost je primarna u odnosu na istinitost iskaza (usp. 12, $14^{\mathrm{b}} 11-13$ ) te $\mathrm{u}$ tom svjetlu treba tumačiti i Aristotelovu riječ

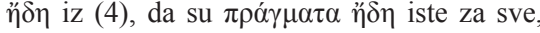
odnosno da prethode $\pi \alpha \theta \dot{\eta} \mu \alpha \tau \alpha$.

Scott Carson tako razlikuje afekcije duše afekcije u duši. Prema njegovoj interpretaciji prvom se frazom govori o sposobnosti duše da bude aficirana, dok se drugom frazom govori o tome da su ti podaci upravo pohranjeni u duši. Međutim, između ove dvije fraze uopće ne treba postojati sadržajna razlika i nema tekstualne potvrde da ih Aristotel strogo razlikuje, odnosno da ih ne koristi kao istoznačnice. Usp. Scott Carson, »Aristotle on Meaning and Reference «, History of Philosophy Quarterly 20 (2003) 4, str. 319-337, str. 322.

5

Aristotel u Kategorijama (5, 4 $\left.{ }^{\mathrm{a}} 26,4^{\mathrm{b}} 1\right)$, osim što govori o tome kako iskaz ( $\lambda$ ó $\gamma$ os) može biti istinit, na osnovi činjenica dodaje i vjerovanje ( $\delta$ ó $\xi \alpha)$. Naime, nečiji iskaz koji pretendira objelodaniti zbilju i biti istinit $\mathrm{u}$ konačnici izražava nečije vjerovanje, odnosno kombiniranu misao čiji su konstituensi jednostavne misli kao significata onoga što se izriče bez sastavljanja. Aristotel u Kategorija$m a$, doduše, uvijek govori o tome da ono što se izriče nesastavljeno označava predmete iz kategorijske razdiobe, a ne predmete $\mathrm{u} u m u$, ali sama činjenica da govori o vjerovanjima paralelno s iskazima jasno ukazuje da pretpostavlja i razinu mentalnih entiteta.

John L. Ackrill u komentaru pridruženom prijevodu djela: Aristotel, Categories and de Interpretatione, preveo John L. Ackrill, Oxford University Press, Oxford 1963., str. 113.

N. Kretzmann, "Aristotle on Spoken Sound Significant on Convention«, str. 11.

Aristotelov se konvencionalizam sastoji u mogućnostima dogovora koju ćemo materi- jalnu stranu jezičnog znaka pridružiti sadržaju. Neki skup glasova tek postaje ime po dogovoru (usp. De int. 2, 16 26-27), kada postane kodirani simbol za taj i taj dojam u duši. Ovakva je pozicija suprotstavljena naturalizmu u Platonovu Kratilu jer se ondje tvrdi da je u samom imenu sadržana narav predmeta. Imena jasno mogu konotirati neka obilježja, primjerice catfish ili peixe-gato jer su se Englezi i Portugalci dogovorili da će imenom konotirati brkove na ribi koju na hrvatskom zovemo »som«. Međutim, Englez, Portugalac i Hrvat imaju isti dojam u duši glede naravi spomenutog slatkovodnog proždrljivca, iako su taj dojam u duši različito kodirali u jeziku.

Lambert M. de Rijk, Aristotle: Semantics and Ontology (vol. 1), Brill, Leiden, Boston, Köln 2002., str. 20

10

L. M. de Rijk, Aristotle, str. 23.

11

S. Carson, »Aristotle on Meaning and Reference $\ll$, str. 323.

12

Simon Noriega-Olmos, Aristotle's Psychology of Signification, De Gruyter, Berlin, Boston 2013., str. 114-115.

13

L. M. de Rijk, Aristotle, str. 23.

14

S. Carson, »Aristotle on Meaning and Reference $\ll$, str. 323.

15

Mark Wheeler nudi identično shvaćanje nalikovanja pozivajući se na 8. poglavlje Kategorija (9 $\left.{ }^{\mathrm{b}} 33-34\right)$, gdje Aristotel tvrdi da su dojmovi u duši određene kvalitete duše. A budući da su stvari slične ili neslične na osnovi kvaliteta, Wheeler zaključuje da Aristotel kazujući da dojmovi u duši nalikuju stvarima zapravo podrazumijeva da imaju iste kvalitete. Usp. Mark R. Wheeler, »Semantics in Aristotle's Organon «, Journal of the History of Philosophy 37 (1999) 2, str. 191-226, str. 205, doi: https://doi.org/10.1353/hph.2008.0810.

16

S. Noriega-Olmos, Aristotle's Psychology of Signification, str. 114-115. 
forma « i osjetilo takve forme prima od vanjskog predmeta bez građe, baš kao što vosak prima znak pečata bez željeza ili zlata. Radi se, naime, o tome da je naše osjetilo aficirano od strane vanjskog predmeta čiju osjetilnu formu prihvaća. ${ }^{17}$ Prema tome, možemo konstatirati da pri osjetilnoj zamjedbi primamo takav sadržaj ( $\alpha i \sigma \theta \eta ́ \mu \alpha \tau \alpha)$ koji ima istu osjetilnu formu kao i vanjski zamijećeni predmet ( $\alpha i \sigma \theta \eta \tau o ́ v$ ). Naravno, ta je forma u predmetu osjetilne zamjedbe instancirana u materiji, dok je u osjetilnom dijelu duše, tj. sposobnosti osjetilnog zamjećivanja primljena bez materije.

Nas ipak najviše zanima kako misli kao $\pi \alpha \theta \eta \dot{\mu} \alpha \tau \alpha$ nastaju, no Aristotel tvrdi da postoji neka vrsta paralelizma između osjetilne zamjedbe i mišljenja. Pogledajmo sljedeći citat.

»Ako je mišljenje poput osjetilne zamjedbe onda bi ono bilo neka vrsta aficiranosti od strane predmeta mišljenja ili nešto drugo takvo. Mišljenje dakle treba biti neaficirano, ali sposobno za primanje formi te potencijalno takvo, ali ne biti to. Slično pak kako se sposobnost za osjetilnu zamjedbu odnosi prema predmetima osjetilne zamjedbe tako se i mišljenje odnosi prema predmetima mišljenja.« (De an. III.4, 429a13-18)

Prema Aristotelu, mišljenje se odvija analogno osjetilnoj zamjedbi. Naime, u slučaju mišljenja radi se također o aficiranosti sličnoga sličnim te o sposobnosti primanja forme. Sukladno rečenome, vanjski predmet i sadržaj mišljenja su slični (ő nje nisu identični, nego samo slični procesi jer se razlikuju u naravi sadržaja, tj. kvalitete koju um prima i koju dijeli s vanjskim predmetom. Sadržaj osjetilne zamjedbe ( $\alpha i \sigma \theta \eta \dot{\mu} \mu \alpha \tau$ ) postoji samo onda kada je osjetilo aktualno afici-

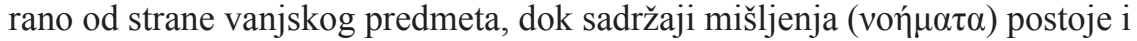
kada predmet mišljenja (voךtóv) nije prisutan (usp. De an. II.5, 417 $24-25$ ), što u konačnici znači da možemo misliti o predmetima kada nismo u njihovoj prisutnosti. Razlog je tome činjenica da kvaliteta koja je prisutna kod osjetilne zamjedbe nije ona kvaliteta koja je prisutna kod mišljenja, iako su obje instancirane $\mathrm{u}$ istom konkretnom materijalnom predmetu. Kada govorimo o osjetilnoj zamjedbi, ona se odnosi na primanje osjetilnih formi i uvijek se tiče nečeg pojedinačnog, dok su predmeti mišljenja inteligibilne forme koje se tiču onog univerzalnog (usp. II.5, 417 23 ).

Iz svega rečenoga jasno je da misli mogu adekvatno nalikovati, tj. dijeliti iste kvalitete kao i vanjski predmeti. Što se tiče naših pitanja iz uvoda, sada možemo konstatirati da su significata jednostavnih značenjskih izričaja misli u kojima je sadržana inteligibilna forma izvanjezičnih i izvanmentalnih predmeta. Relacija nalikovanja pak označava rezultat kauzalne relacije aficiranosti sličnoga sličnim, gdje su nalika i odgovarajući vanjski predmet izomorfični, odnosno tipski identični, ali ne i numerički jer »mišljenje je sposobno primiti formu (...) ali ne biti to«. S druge strane, naša je duša, tj. točnije umski dio strukturiran tako da po svojoj prirodi može spoznavati i uhvatiti takav formalni i nužni aspekt zbilje. ${ }^{18} \mathrm{U}$ tom su slučaju problemi tipične mentalističke teorije riješeni jer reći da je značenje termina ‘čovjek' misao ili pojam čovjeka jest istovjetno s time da se kaže da je značenje riječi ‘čovjek' formalno-nužni i univerzalni aspekt koji ima svaka takva pojedinačnost - naime to da je dvonožna kopnena životinja. Što se tiče novih i neizrečenih rečenica, uz pravila sintakse i poznavanje značenja riječi, kompozicijski se određuje značenje bilo koje (složene) rečenice na osnovi identificiranja složene kombinirane misli koja ima istinitosnu vrijednost (usp. De anima III.6). Najizazovniji prigovor o subjektivnosti misli također se lako odbacuje na osnovi činjenice da je u našim mislima prisutan upravo onaj nužni i univerzalni aspekt koji izvanmentalni predmeti instanciraju. 
III.

\section{I.}

U Aristotelovu korpusu, a posebno u spisu $O$ duši, postoje, međutim, brojni odlomci koji bi mogli sugerirati da su $\varphi \alpha v \tau \alpha ́ \sigma \mu \alpha \tau \alpha$ sadržaji čina mišljenja, odnosno da su inteligibilne forme kao $\varphi \alpha v \tau \alpha ́ \sigma \mu \alpha \tau \alpha$ nalike vanjskih predmeta. Wheeler ${ }^{19}$ se tako poziva na De anima II.8 gdje Aristotel govori da je glas zvuk koji ima značenjsku komponentu i da ga kao takvog prati sposobnost (slikovnog) predočavanja, tj. $\varphi \alpha v \tau \alpha \sigma i ́ \alpha$. Iz toga Wheeler zaključuje da su mentalne (slikovite) predodžbe sadržaj izgovorenih zvukova, odnosno da su označena $\pi \alpha \theta \eta \dot{\eta} \mu \alpha \alpha$ ili sadržaji percepcije ( $\alpha i \sigma \theta \eta \dot{\mu} \mu \alpha \tau \alpha)$ ili sadržaji sposobnosti predočavanja ( $(\alpha \nu \tau \alpha \dot{\sigma} \sigma \mu \alpha \tau \alpha)$. Intrigantno jest to što Wheeler ne negira postojanje inteligibilnih formi, odnosno predmeta mišljenja, ali smatra ${ }^{20}$ da inteligibilne forme kao predmete mišljenja s vanjskim predmetima dijele $\varphi \alpha v \tau \alpha ́ \sigma \mu \alpha \tau \alpha$, a ne vớ $\mu \alpha \tau \alpha$. Naime, kada Aristotel kaže (usp. II.8, 431 ${ }^{\mathrm{b}} 21-22$ ) da su postojeće stvari ili predmeti percepcije ili predmeti mišljenja, Wheeler ${ }^{21}$ smatra da $\varphi \alpha v \tau \alpha ́ \sigma \mu \alpha \tau \alpha$ nalikuju stvarnosti jer ona dijele s vanjskim predmetima i osjetilne i inteligibilne forme. Prema tome, jezik doista označava misli, ali na taj način da označi sadržaj koji je dan u mentalnoj slici, koje pak mislećem dijelu duše prezentiraju formalne kvalitete stvari.

Modrak ima slično mišljenje oko significata jednostavnih značenjskih izričaja. Ona, ${ }^{22}$ naime, smatra da su $\pi \alpha \theta \eta ́ \mu \alpha \tau \alpha$ nalike vanjskih predmeta i značenja naših izričaja, međutim naša $\pi \alpha \theta \eta ́ \mu \alpha \tau \alpha$ mogu nalikovati vanjskim stvarima - te na taj način osigurati referenciju naših riječi na stvari - samo ako su $\varphi \alpha v \tau \alpha ́ \sigma \mu \alpha \tau \alpha$. Modrak se oslanja na evidenciju iz spisa $O$ pamćenju gdje Aristotel tvrdi (451 $15-16)$ da je pamćenje stjecanje predodžbe (

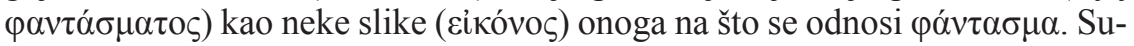
kladno tome, mi smo sposobni primiti osjetilni podatak od vanjskih predmeta,

17

Glede spomenute aficiranosti, postoje dvije osnovne interpretacije. Prema prvoj osjetilo doista postaje npr. crveno, $\mathrm{tj}$. preinačuje se u crveno kada se zamjećuje crveni predmet, dok prema drugoj osjetilo tek prima osjetilnu formu crvenoga bez da je samo pocrvenilo zato što je ta forma kodirana na drugačiji način, baš kao što se neki glazbeni komad može kodirati na gramofonsku ploču. Moj argument ne ovisi o prihvaćanju jedne od ovih interpretacija, nego se oslanja samo na činjenicu da osjetilni dio duše prima istu kvalitetu kao i vanjski predmet.

18

Slična se interpretacija u većoj ili manjoj mjeri također nalazi kod S. Carsona (»Aristotle on Meaning and Reference«), D. Charlesa (David Charles, Aristotle on Meaning and Essence, Oxford University Press, Oxford, 2010.), djelomično D. K. W. Modrak (Deborah K. W. Modrak, Aristotle's Theory of Language and Meaning, Cambridge University Press, Cambridge 2001.) te S. Noriega-Olmosa (Aristotle's Psychology of Signification). Za suprotno mišljenje, kao što smo već vidjeli J. Ackrill (Aristotle's Categories and de Interpretatione) i N. Kretzmann (»Aristotle on
Spoken Sound Significant on Convention «) te kao što ćemo u nastavu vidjeti M. R. Wheeler (»Semantics in Aristotle's Organon«), J-L. Hudry (Jean-Luis Hudry, »Aristotle on Meaning«, Archiv für Geschichte der Philosophie 93 (2001), str. 253-280, doi: https://doi. org/10.1515/AGPH.2011.012) te djelomično D. K. W. Modrak (Aristotle's Theory of Language and Meaning).

19

M. R. Wheeler, »Semantics in Aristotle's Organon«, str. 202-204.

20

Ibid. str. 205 .

21

Ibid. str. 208.

22

Usp. D. K. W. Modrak, Aristotle's Theory of Language and Meaning, str. 234; Deborah K. W. Modrak, »Philosophy of Language«, u: Marie L. Gill, Pierre Pellegrin (ur.), $A$ Blackwell Companion to Ancient Philisophy, Blackwell, Malden, Oxford, Victoria 2009., str. $640-663$, str. 653 . 
a kada predmeti više nisu prisutni, ostaju nam u pamćenju njihove slike kao $\varphi \alpha v \tau \alpha ́ \sigma \mu \alpha \tau \alpha$. Naše riječi označavaju određene $\pi \alpha \theta \eta \dot{\mu} \mu \alpha \tau \alpha$, a mi našim riječima uspijevamo referirati na svijet upravo zato što su ta $\pi \alpha \theta \eta \dot{\mu} \mu \alpha \tau \alpha$ mentalne slikovite predodžbe koje fotografijski nalikuju vanjskim stvarima. Međutim, Modrak $^{23}$ je svjesna da značenje mora biti nešto univerzalno i esencijalno, dok su $\varphi \alpha v \tau \alpha ́ \sigma \mu \alpha \tau \alpha$ slike osjetilnih svojstava predmeta. Upravo iz tog razloga uvodi ${ }^{24}$ dvostruko nalikovanje, naime $\varphi \alpha v \tau \alpha ́ \sigma \mu \alpha \tau \alpha$ nalikuju vanjskim predmetima kojih su slike i dijele s njima osjetilnu formu, međutim, kada se

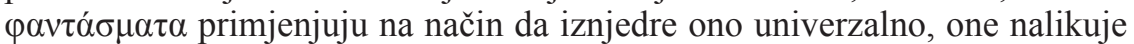
predmetu tako što prezentiraju njegovu narav.

Za značenje je dakle ključno ovo drugo nalikovanje jer na taj način $\varphi \alpha v \tau \alpha ́ \sigma \mu \alpha \tau \alpha$ iznjedruju $\lambda$ ó os tog predmeta. Pod logosom Modrak podrazumijeva realnu definiciju u kojoj je prisutan univerzalni i nužni aspekt materijalnih predmeta. U tom se slučaju $\pi \alpha \theta \eta \dot{\mu} \mu \tau \alpha$ kao $\varphi \alpha v \tau \alpha ́ \sigma \mu \alpha \tau \alpha$ odnose na primjerak, a $\pi \alpha \theta \eta \dot{\mu} \mu \alpha \tau \alpha$ kao značenje na samu narav tipa kojemu taj primjerak pripada. Prema tome, $\varphi \alpha v \tau \alpha ́ \sigma \mu \alpha \tau \alpha$ imaju ključnu ulogu jer predočavaju i osjetilne podatke, ali i iznjedruju inteligibilnu formu koja proizlazi upravo iz osjetilnih karakteristika. ${ }^{25}$ Slično razmišlja i Hudry ${ }^{26}$ kada tvrdi da je značenje prisutno u realnoj definiciji, no opet kao i Modrak, prihvaćanje u misli tih univerzalnih i nužnih

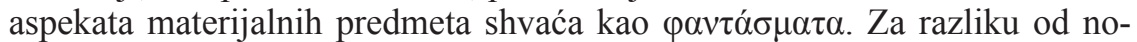
minalne definicije, koja je jezično značenje, realna je prema Hudry ontološki alat, pomoću kojega naše riječi uspijevaju biti o svijetu, ali upravo na način da je značenje riječi afekcija od strane vanjskog svijeta, pri čemu $\varphi \alpha v \tau \alpha ́ \sigma \mu \alpha \tau \alpha$ igraju ključnu ulogu jer se vanjski predmeti misle u slikama te je upravo pomoću slikovnog nalikovanja uspostavljen odnos između misli i svijeta.

Sukladno rečenome možemo, dakle, vidjeti da iako postoji konsenzus oko toga da je značenje nešto univerzalno i nužno, tj. nešto što predstavlja samu narav stvari koja je mišljenju dana preko inteligibilne forme i dalje bismo mogli sumnjati u dosadašnju interpretaciju prema kojoj su $\pi \alpha \theta \eta \dot{\mu} \mu \alpha \alpha$ kao significata zapravo voฑ́ $\mu \alpha \tau \alpha$, a ne $\varphi \alpha v \tau \alpha ́ \sigma \mu \alpha \tau \alpha$. Naime, vidjeli smo da čak i ako doista voฑ́ $\mu \alpha \tau \alpha$ jesu označena našim riječima, opet je njihov sadržaj mentalna slika pomoću koje se fotografijski zrcali zbilja u našoj duši. Do sada smo, međutim, ignorirali one odlomke iz spisa $O d u s ̌ i$ u kojima se analiziraju $\varphi \alpha v \tau \alpha ́ \sigma \mu \alpha \tau \alpha$ te vjerojatno iz tog razloga ne možemo uvažiti ulogu sposobnosti slikovnog predočavanja u formiranju značenja. S druge strane, Wheeler, Modrak i Hudry koncentriraju se upravo na te odlomke, koji sugeriraju da $\varphi \alpha v \tau \alpha \sigma i ́ \alpha$ ima ključnu ulogu u određivanju značenja, pa čak i ako značenje shvatimo kao univerzalni i nužni aspekt izvanmentalnih stvari. Upravo iz ovih razloga treba detaljnije promotriti neke retke iz trećeg poglavlja treće knjige spisa $O$ duši kao i retke iz sedmog i osmog poglavlja iste knjige, gdje Aristotel govori o razlici između

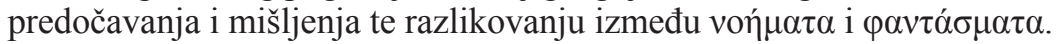

\section{II.}

U trećem poglavlju treće knjige spisa $O$ duši Aristotel nastoji pozitivno odrediti sposobnost predočavanja te ju razlučiti od uma i osjetilne zamjedbe. Tumači koji smatraju da su $\varphi \alpha v \tau$ ó $\sigma \mu \alpha \tau \alpha$ značenja, odnosno da je u njima prisutna inteligibilna forma, pozivaju se na sljedeće retke:

»Predočavanje jest nešto drugo doli osjetilno zamjećivanje i mišljenje, ali ono ne nastaje bez osjetilnog zamjećivanja, a bez predočavanja pak nema ni koncipiranja.« (De an. III.3, 427b14-16)

»Što se tiče mišljenja, budući da je ono nešto drugo doli osjetilno zamjećivanje, čini se da tome pripadaju i koncepcije i predodžbe [=mentalne slike] (...). Ako je dakle predočavanje ono na osnovi čega kažemo da neka predodžba [=mentalna slika] nastaje u nama, i to ne kažemo na metaforički način (...).« (De an. III.3, 427b27-428 3 ) 
Iz ovoga neki intepreti zaključuju otprilike ovako: (1) sposobnost predočavanja je ono na osnovi čega (slikovite) predodžbe nastaju u nama; (2) predodžbe pripadaju mišljenju; (3) nema koncipiranja bez (slikovitog) predočavanja, dakle (4) mentalne su slike upravo ono što pomišljamo, tj. naše su koncepcije stvari upravo oni podaci koji su prisutni u mentalnoj slici. Međutim, Aristotelov je interes upravo pokazati da predočavanje nije koncipiranje (usp. III.3, $\left.427^{\mathrm{b}} 16-17\right)$ jer predočavanje ovisi o nama, dok vjerovanje ovisi o svijetu. Iskustvo osjetilne zamjedbe ima tek omogućujuću ulogu jer osigurava sadržaj koji naša sposobnost predodžbe može po volji prekrajati. Ništa ne prijeći da trenutno u glavi imam slikovitu predodžbu zelene lastavice sve dok sam imao iskustvo sa zelenim stvarima i lastavicama. Međutim, vjerovanje da je lastavica zelena jest istinito ili neistinito u odnosu na stanje stvari u svijetu.

U ostatku poglavlja Aristotel nastoji pokazati da predočavanje nije identično ni sa sposobnosti osjetilne zamjedbe, zbog toga što se predočavanje može, poput misli, odvijati i kada predmet predočavanja nije prisutan (usp. III.3, 428 a $6-8$ ). Osjetilna zamjedba predmeta jest nadalje uvijek točna - jer se prima osjetilna forma predmeta, ${ }^{27}$ kao što je i znanje uvijek istinito - međutim predočavanje može biti pogrešno (usp. III.3, 428 $8^{\mathrm{a}} 11-12$ ). Aristotel se dalje pita može li se predočavanje poistovjetiti s vjerovanjem jer i vjerovanje može biti pogrešno. Međutim, predočavanje nije vjerovanje jer vjerovanje pretpostavlja koncipi-

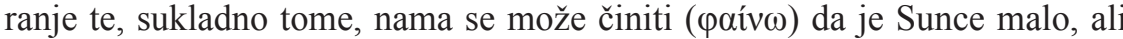
zbog ispravne koncepcije Sunca mi vjerujemo da je ono veće od Zemlje (usp. III.3, 428 $1-5)$. Prema tome, iz ovoga je jasno da se predočavanje ne može poistovjetiti sa sposobnosti mišljenja koje se odvija u inteligibilnim formama jer inteligibilne forme uvijek pripadaju određenom predmetu, dok naša predodžba predmeta ne mora biti valjana.

Međutim, u sedmom poglavlju Aristotel kaže (usp. III.7, 431 ${ }^{\mathrm{a}} 17$ ) da duša ni-

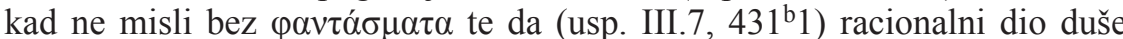

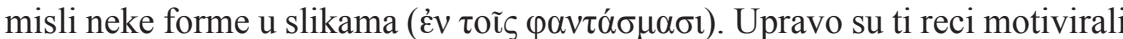
Hudry, Whellela i Modrak da zaključe kako se inteligibilne forme prihvaćaju u slikama na fotografijski način jer, kao što je prije konstatirano, predočavanje ovisi o osjetilnoj zamjedbi predmeta. ${ }^{28}$ Naime, pomoću recepcije osjetilne

23

Usp. D. K. W. Modrak, Aristotle's Theory of Language and Meaning, str. 257.

24

Usp. ibid., str. 259; D. K.W. Modrak, »Philosophy of Language $\ll$, str. 653.

25

Usp. D. K. W. Modrak, Aristotle's Theory of Language and Meaning, str. 257.

26

J-L. Hudry, »Aristotle on Meaning«, str. 269-270.

27

O osjetilnom zamjećivanju zapravo ne bismo trebali govoriti veridički u smislu da je istinito ili neistinito jer se ono, za razliku od iskaza i kombiniranih misli, tj. vjerovanja, ne tiče toga da je nešto u zbilji sastavljano ili rastavljeno, nego jednostavno zamjećujemo nešto bijelo, hrapavo, glasno i sl. Naravno, o zamjećivanju možemo govoriti kao pogrešnom kada je predmet opažanja prisutan u akcidentalnom smislu. Primjerice, kada opažamo bijelog Dijareva sina, to da je bijel opažamo po sebi, ali to da je Dijarev sin u akcidentalnom smislu. Naime, glede toga je li ovaj bijeli čovjek Dijarev mogli bismo pogriješiti, dok glede njegove boje puti ne (usp. De an. II.6, $\left.418^{\mathrm{a} 20}-23\right)$.

28

Zapravo, sve naše osjetilne i kognitivne sposobnosti u konačnici izviru iz neposredne osjetilne zamjedbe vanjskog predmeta. To je jasno također iz 19. poglavlja druge knjige Druge analitike, gdje se objašnjava kako se iz pojedinačne percepcije vanjskih predmeta postepeno razvijaju memorija, iskustvo, umijeće i u konačnici znanje kao opći princip. U tom svjetlu treba tumačiti i 8. poglavlje treće knjige spisa $O$ duši gdje Aristotel kaže da bez osjetilne zamjedbe predmeta ne bi bilo moguće ni znanje ni razumijevanje. Ovakve stavove treba shvatiti kao Aristotelov empi- 
forme mi također, zahvaljujući sposobnosti predočavanja ( $\varphi \alpha v \tau \alpha \sigma i ́ \alpha)$ uspijevamo uhvatiti i inteligibilnu formu u slici koja je onda kao takva prisutna $\mathrm{u}$ mišljenju (usp. De an. III.8, 432a4-9). Hudry ${ }^{29}$ tako konstatira da je $\varphi \alpha v \tau \alpha \sigma^{\text {á́ }} \alpha$ most između pojedinačne percepcije i univerzalnog suđenja, Wheeler ${ }^{30}$ pak da su $\varphi \alpha v \tau \alpha ́ \sigma \mu \alpha \tau \alpha$ sadržaji čina mišljenja te da naš jezik doista izražava formalne i kauzalno učinkovite kvalitete stvari, ali da su one mislećem dijelu duše prezentirane kroz $\varphi \alpha v \tau \alpha ́ \sigma \mu \alpha \tau \alpha$, dok Modrak $^{31}$ tvrdi da se i osjetilni i kognitivni sadržaj našem umu daje kroz $\varphi \alpha v \tau \alpha ́ \sigma \mu \alpha \tau \alpha$.

Spomenuti Aristotelovi reci uopće nas ne moraju voditi takvim zaključcima iz dva razloga. Prvo, mogli bismo tvrditi da se u tim recima uopće ne misli na teorijski, nego na praktični um. ${ }^{32}$ Naime, kada razmišljamo treba li pobjeći od neke životinje u šumi, njena je predodžba u nama, na osnovi prvog bliskog susreta, sasvim dovoljna da nas stavi u panični pokret u suprotnom smjeru. Budući da smo konstatirali da nas u spisu $O$ tumačenju zanimaju koncepcije stvari, koje ćemo kombinirati u istinitosno-vrijednosnim sudovima za svrhu naših istraživanja i potrage za znanjem, ovi nas Aristotelovi reci uopće ne trebaju zabrinjavati jer se odnose na praktično rasuđivanje koje ima za cilj djelovanje. No čak i da se ovi reci odnose na teorijsko rasuđivanje, opet ne bi trebali predstavljati problem. Što je problematično u tome da duša neke forme misli u slikama? Naime, ako razmišljam o tome ima li pastrva škrge, do afirmativnog ću odgovora doći znajući da je pastrva prije svega riba, odnosno da je za pastrvu 'biti riba' nešto nužno i formativno, a budući da je također 'škrgovitost' nužno i univerzalno svojstvo riba, zaključujem da pastrva doista ima škrge. Cijeli je ovaj misaoni lanac potpuno neovisan o tome predočavam li sebi porcijašicu u pećnici ili trofejni primjerak u Savi Bohinjki. Naime, mogao bih u svojoj predodžbi pogriješiti oko toga je li porcijašica dugačka $30 \mathrm{~cm}$ ili $35 \mathrm{~cm}$ ili ima li trofejni primjerak $15 \mathrm{~kg}$ ili $17 \mathrm{~kg}$, ali po pitanju inteligibilne forme pastrve nema greške.

\section{III.}

U prošlom smo potpoglavlju vidjeli da Aristotelove navode o tome kako $\varphi \alpha v \tau \alpha ́ \sigma \mu \alpha \tau \alpha$ uvijek prate misli ne treba shvatiti kao da se misli i $\varphi \alpha v \tau \alpha ́ \sigma \mu \alpha \tau \alpha$ mogu izjednačiti, štoviše mišljenje i predočavanje bi se moglo, kako Charles kaže, događati simultano. ${ }^{33}$ Naime, imati u mišljenju formalni i nužni aspekt stvarnosti ne isključuje da nam ta stvar bude prisutna u mišljenju kao ovakva ili onakva. Tako Noriega-Olmos s pravom tvrdi da dok su misli iste za sve, $\varphi \alpha v \tau \alpha ́ \sigma \mu \alpha \tau \alpha$ nisu jer u njima nije prisutan primaran aspekt predmeta. ${ }^{34} \mathrm{Na}-$ ime, u $\varphi \alpha v \tau \alpha ́ \sigma \mu \alpha \tau \alpha$ je prisutno nešto sekundarno predmetima, ono što može biti ovakvo ili onakvo i u čemu možemo pogriješiti u svojom predodžbama. Upravo iz tog razloga Noriega-Olmos u spisu $O$ tumačenju rečenicu (4) čita kao da su naše riječi znaci upravo tog primarnog $(\pi \rho \omega ́ \tau \omega v)^{35}$ aspekta stvarnosti, a ne da primarno označavaju misli, a sekundarno stvari. Naglasak je točno na tome da je Aristotel, razvijajući znanstveno relevantan jezik, bio zainteresiran da naše riječi označavaju bitna i primarna svojstva stvari, a ne sekundarna, koja mogu biti čas ovakva čas onakva. Naravno, posve je moguće riječima označavati i ta, odnosno ona koja su prisutna u $\varphi \alpha v \tau \alpha ́ \sigma \mu \alpha \tau \alpha$, ali ta svojstva za potrebe spisa $O$ tumačenju, kao ni za dijalektičko i demonstrativno zaključivanje nisu relevantna.

Ovakvo su sužavanje Aristotelova interesa za jezik, kako smo vidjeli, primijetili Modrak i Hudry, tvrdeći da je tek u realnoj definiciji prisutno pravo značenje neke riječi, odnosno da je označena takva $\pi \alpha ́ \theta \eta \mu \alpha$ koja je ontološki alat jer dovodi u odnos riječ i svijet. Hudry, međutim, smatra da nominalne definicije 
nisu na taj način ontološki alat te da one predstavljaju tek jezično značenje, za razliku od $\pi \alpha \theta \eta \dot{\mu} \mu \alpha \tau \alpha$ koje predstavljaju nejezično značenje. Svakako je točno da su $\pi \alpha \theta \eta \dot{\mu} \mu \alpha \tau \alpha$ koja se kodiraju kroz realnu definiciju ontološki alat i da nam pomažu u identificiranju elemenata zbilje, međutim tvrditi da nominalna definicija predstavlja tek jezično značenje bez odnosa prema stvarnosti jest ili pogrešno ili dvosmisleno. Naime, ispravno je ako Hudry hoće reći da se nominalnim definicijama naznačava kako se neka riječ upotrebljava, dok realnima usput uspijevamo dovesti u odnos riječ i pojedinog pripadnika kategorijske sheme zajedno s njegovim diferencijalnim svojstvima, ${ }^{36}$ međutim, ako hoće reći da nominalne definicije ne ostvaruju na isti način značenje kao i realne - to je pogrešno.

Aristotel tvrdi da termini poput 'kentaur' i 'jaracjelen' imaju značenje jer označuju nešto (usp. De int. 1, 16 ${ }^{\mathrm{a}} 17-18$ i Apo. II.7, 92 ${ }^{\mathrm{b}} 6-7$ ), odnosno, kao što smo do sada ustanovili, označavaju neku $\pi \alpha ́ \theta \eta \mu \alpha$. Ta $\pi \alpha ́ \theta \eta \mu \alpha$ je neka koncepcija, odnosno jedinstvena misao koja na neki način mora biti nalika izvanmentalne stvarnosti. Međutim, u stvarnosti nema kentaura i jaracjelena čiju bismo inteligibilnu formu mogli uhvatiti i formirati jedinstvenu misao, stoga se postavlja pitanje na osnovi čega su ti termini značenjski, odnosno na koji način označena $\pi \alpha ́ \theta \eta \mu \alpha$ nalikuje stvarnosti. Ključan uvjet da neki termin nešto znači jest da označava jedinstvenu koncepciju, naime nešto jedno, no ta jedinstvena koncepcija ne mora nužno biti nalika nečeg jednog i u izvanmentalnoj stvarnosti. Naime, ništa ne prijeći da na osnovi iskustva više prirodnih

rizam u suprotnosti s Platonovim racionalizmom. Naime, Platon smatra da naša duša posjeduje znanje o idejama, ali ga rođenjem, tj. utjelovljenjem zaboravlja, stoga se kroz život moramo podsjećati onoga što je duša oduvijek znala. Aristotel se slaže da se znanje tiče univerzalnoga, međutim, mi ništa ne zaboravljamo, nego jednostavno moramo opažati vanjski svijet kao početni korak u potrazi za znanjem univerzalnoga.

29

J-L. Hudry, »Aristotle on Meaning«, str. 269.

30

M. R. Wheeler, »Semantics in Aristotle's Organon«, str. 205-206.

31

D. K. W. Modrak, Aristotle's Theory of Language and Meaning, str. 236-237.

32

Tako, primjerice, smatra Shields u komentaru. Usp. Aristotel, De Anima, preveo Cristopher Shields, Oxford University Press, Oxford 2016., str. str. 339. Međutim, praktično djelovanje uvijek može biti utemeljeno na teoretskim razmatranjima, odnosno teško je reći kada smo se na neko praktično djelovanje odlučili na osnovi jednostavne slikovite predodžbe, a kada je naše djelovanje konkluzija praktičnog silogizma.

33

D. Charles, Aristotle on Meaning and Essence, str. 138 .
34

S. Noriega-Olmos, Aristotle's Psychology of Signification, str. 128-129.

35

Ovakvo je čitanje primijenjeno na početku ovog teksta, a prisutno je još i kod Amonija, u kritičkom izdanju teksta Minio-Paluella, Whitakera te Noriega-Olmosa. Usp. Aristotelis Categoriae et liber De Interpretatione, recognovit brevique adnotatione critica instruxit L. Minio-Puluello, Oxonii, 1974.; C. W. A. Whitaker, Aristotle's De Interpretatione: Contradiction and Dialectic, Oxford University Press, Oxford 1996.; S. Noriega-Olmos, Aristotle's Psychology of Signification. Amonije doduše smatra da su misli posrednici u označavanju stvari u smislu da su one označene direktno, a stvari indirektno, ali ako primijenimo dosadašnje shvaćanje relacije nalikovanja, prema kojoj su misli i stvari tipski identične označiti prvotne dojmove u duši znači u isto vrijeme označiti i prvotan aspekt stvarnosti, naime njihove inteligibilne forme. 36

U Drugoj analitici (Apo. II.7, 92b4-7) tako Aristotel objašnjava da mi ne možemo znati što jest jaracjelen jer to pretpostavlja navođenje esencijalnog obilježja u realnoj definiciji, što automatski implicira egzistenciju. Takvo biće, međutim, ne postoji, stoga ne može imati ni esencijalna obilježja jer ona specificiraju što za nešto znači biti. Ipak, moguće je znati što izraz ‘jaracjelen' označava, odnosno moguće je razumjeti neki logos koji specificira koncepciju jaracjelena. 
vrsta uhvativši njihove inteligibilne forme formiramo misao nekog fikcijskog bića. Primjerice, misao kentaura smo koncipirali na osnovi iskustva s ljudima i s konjima, odnosno na osnovi njihovih inteligibilnih formi. Sukladno tome, riječ 'kentaur' označava takvu misao koja se u jeziku kodira kao 'životinja s tijelom konja i glavom čovjeka', tj. kao nominalna definicija riječi 'kentaur'. ${ }^{37}$ Prema tome, nominalne definicije pomoću kojih se definiraju nepostojeći predmeti također predstavljaju svojevrsno sintaktičko jedinstveno, odnosno jedinstvenu misao kao i realne, s time da realne ${ }^{38}$ upućuju i na ontološko jedinstvo ${ }^{39}$ jer imati neku realnu definiciju znači imati i objašnjenje zašto nešto postoji kao individua u ontološkom smislu. ${ }^{40}$

Dakle, nereferirajući termini, prema Hudryjevoj terminologiji, također izražavaju nejezičnu misao. Razlika je jedino ta da značenje takvih termina mi doslovno kombiniramo i stvaramo na osnovi naših sposobnosti primanja inteligibilnih formi iz više različitih bića. Međutim, sada se postavlja pitanje referencije. Mnogi tumači, neovisno o tome priklanjaju li se mišljenju da su significata čista voń $\mu \alpha \tau \alpha$ kao fundamentalni aspekt zbilje ili $\varphi \alpha v \tau \alpha ́ \sigma \mu \alpha \tau \alpha$ koja taj fundamentalni aspekt daju mislima, smatraju da significatum kao ó oí $\omega \mu \alpha$ fiksira referenciju. ${ }^{41}$ Ovakvo je mišljenje sasvim prirodno na osnovi naravi relacije nalikovanja. Naime, ako mi našim riječima označavamo jedinstvenu koncepciju nekog predmeta, a ta voฑ́ $\mu \alpha \tau \alpha$ jesu kauzalno uzrokovana od tipski identičnog formalnog aspekta stvari, logično je misliti da je na osnovi takve relacije nalikovanja osigurana referencija naših termina na vanjske predmete. Međutim, referencija nije osigurana nalikovanjem jer bi u tom slučaju i termini poput 'kentaur' i 'jaracjelen' referirali. Crivelli ${ }^{42}$ doduše misli da su takvi termini kompleksni i da referiraju na čovjeka i konja, odnosno na jarca i jelena, međutim posve je jasno da, kada kažem 'kentaur', ne namjeravam govoriti o dvjema stvarima, nego o točno jednoj koju koncipiram tako i tako. Referencija, dakle, nije osigurana nalikovanjem jer postoje posve smisleni nereferirajući termini. Nalikovanje zapravo osigurava tek nastajanje misli te omogućuje koncipiranje svakakvih ficta na osnovi inteligibilnih formi raznovrsnih facta. Referencija je zapravo osigurana tek realnom definicijom jer je tek u njoj pored sintaktičkog i noetičkog jedinstva objelodanjeno i ontološko.

U konačnici možemo zaključiti da su significata naših riječi doista misli u kojima je prisutan fundamentalan i nužan aspekt zbilje. Takav nalikujući sadržaj naših misli rezultira na osnovi kauzalnog procesa aficiranja jer imamo takvu psihologiju koja nam omogućuje da budemo aficirani od strane vanjskih predmeta te da na taj način u mišljenje prihvatimo njihove inteligibilne forme. Naime, naše misli nisu ti predmeti, kao što Aristotel i kaže, nego im izomorfično nalikuju, odnosno tek su im tipski identične. Naravno, znanost može biti samo o postojećim stvarima i stoga kada govorimo o nalikovanju, uvijek pretpostavljamo jedinstveni predmet čiju inteligibilnu formu zahvaćamo u umu i koju izražavamo realnom definicijom. Međutim, ne treba misliti da nalikovanje po sebi fiksira referenciju naših termina jer je i sadržaj nereferirajućih, ali značenjskih termina, također pribavljen nalikovanjem. Takve nalike nastaju na osnovi više predmeta, odnosno više inteligibilnih forma, koje u umu formiramo kao jedinstvenu misao. Ipak, u znanstveno relevantnom jeziku zainteresirani smo za postojeće stvari, stoga nam svaka koncepcija predmeta kao nalika ujedno i referira jer je u um pohranjena od jednog predmeta. Referencija je dakle osigurana isključivo realnom definicijom kojom izdvajamo jedinstvene elemente kategorijske razdiobe zajedno $\mathrm{s}$ njihovim specifičnim svojstvima. 
IV.

Aristotelova se psihosemantika razlikuje od tipičnih mentalističkih teorija značenja po tome što osigurava da je significatum u konačnici uvijek utemeljen u izvanmentalnoj realnosti. Naše misli i koncepcije koje su označene jezičnim entitetima tipski su identične nalike fundamentalnog i formalnog aspekta materijalnih predmeta. Prema tome, nema opasnosti od subjektivnosti misli jer one izomorfično reprezentiraju vanjske predmete zahvaljujući takvom psihološkom ustrojstvu koje nam omogućuje recepciju primarnog i nužnog u stvarima. Kretzmannova osuda, dakle, da Aristotel kada govori o nalikovanju afekcija ne govori o psihologiji i epistemologiji, ne može biti dalje od istine jer se upravo u našem psihološkom ustrojstvu nalazi osnova za spoznavanje zbilje, kao i to da se zbilja u konačnici može kodirati u nekom epistemički relevantnom fragmentu jezika. Naime, znati značenje neke riječi znači imati određenu misao, tj. jedinstvenu koncepciju koja se kodira u realnoj definiciji, što pak u konačnici znači jezično artikulirati temeljne odrednice nekog segmenta zbilje. Upravo zbog toga, jasno je da $\varphi \alpha v \tau \alpha \dot{\sigma} \mu \mu \tau \alpha$ ne mogu biti značenja jer se ona prije svega odnose na način danosti predmeta, na to kako nam se nešto čini, a ne na to kako nešto doista jest.

37

Za izvrstan shematski prikaz koncipiranja jedne misli na osnovi inteligibilnih formi više izvanmentalnih entiteta vidi: D. Charles, Aristotle on Meaning and Essence, str. 89.

38

Usp. S. Noriega-Olmos, Aristotle's Psychology of Signification, str. 71-72.

39

U 11. poglavlju spisu $O$ tumačenju također se razmatraju kompleksni predikati i autonomni jezični izričaji te se razlikuju (i) biti dvonožna kopnena životinja, (ii) biti bijeli filozof i (iii) biti dobar postolar. Naime, u odnosa na Sokrata, kada kažemo (i) izrekli smo jedno o jednome jer između svojstava biti dvonožan, biti kopnen i biti životinja vlada nužno jedinstvo te smo tim iskazom smjestili Sokrata $u$ kategorijsku shemu na osnovi pitanja što on jest. Kada u odnosu na Sokrata izreknemo (ii) nismo rekli jedno o jednome, nego kao da smo rekli dva iskaza naime Sokrat je bijel i Sokrat je filozof. Između svojstava biti bijele puti i biti filozof ne postoji nužna veza jer postoje i crnoputi filozofi. Što se tiče trećeg slučaja, ovdje se radi o neautonomnom dijelu kompleksnog predikata kojeg je čak nemoguće rastaviti u više iskaza jer svojstvo biti dobar ne kvalificira subjekta po sebi, nego ga kvalificira akcidentalno - modificira njegov akcident. Naime, ako bi pisalo da je Sokrat dobar čovjek, tada možemo zaključiti da je on dobar, ali iz Sokrat je dobar postolar ne možemo zaključiti da je on dobar.

40

U An.po. II.10, tako saznajemo da 'buka u oblacima uslijed ugasnuća vatre' uspijeva označiti nešto jedinstveno u svijetu - grom, upravo zato što fraza 'buka u oblacima' slijedi kao konkluzija iz silogizma preko srednjeg pojma koji predstavlja objašnjenje, odnosno uzrok buke u oblacima - naime, ugasnuće vatre ili, kako bismo danas rekli, električno pražnjenje.

41

Primjerice, D. K. W. Modrak, Aristotle's Theory of Language and Meaning, str. 236; S. Carson, " Aristotle on Meaning and Reference $\ll$, str. 331.

42

Paulo Crivelli, »Signification and Truth«, u: Georgios Anagnostopoulos (ur.), A Blackwell Companion to Aristotle, Blackwell, Malden, Oxford, Victoria 2019., str. 81-100, str. 89, doi: https://doi.org/10.1002/9781444305661. ch6. 


\title{
Igor Martinjak
}

\section{Aristotle's Psychological Conception

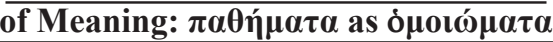

\begin{abstract}
In this paper, I investigate Aristotle's psychological conception of meaning. I will show that in Aristotle's De interpretatione we can find a conception of meaning that enables a response to typical objections such psychological accounts are facing with. According to my interpretation, it is required that thoughts are significata of our terms rather than mental images. Mental images could occur as subjective features of a particular mind in particular portion of time, whereas thoughts as an isomorphic likeness of the universal and necessary aspect of extramental reality provide ground for intersubjectivity required for an adequate account of meaning. In my interpretation, however reference is not fixed via likening relation because a mental content of nonreferring terms is also provided via likening relation between thought and two or many extramental things.
\end{abstract}

\section{Key words}

affections in the soul, thoughts, images, likenesses, extramental reality, meaning, reference 